\title{
Patterns of fish and whale consumption in relation to methylmercury in hair among residents of Western Canadian Arctic communities
}

\author{
Emily V. Walker ${ }^{1,2^{*}}$ D, Yan Yuan², Safwat Girgis ${ }^{3}$ and Karen J. Goodman ${ }^{1}$
}

\begin{abstract}
Background: Methylmercury contamination of the environment represents a substantial environmental health concern. Human exposure to methylmercury occurs primarily through consumption of fish and marine mammals. Heavily exposed subgroups include sport or subsistence fishers residing in Arctic communities. We aimed to estimate the association of fish/whale consumption patterns of Canadian Arctic subsistence fishers with the internal dose of methylmercury as measured in hair.

Methods: This research was conducted within ongoing community projects led by the CANHelp Working Group in Aklavik and Fort McPherson, Northwest Territories and Old Crow, Yukon. We interviewed each participant using a fish-focused food-frequency questionnaire during September-November 2016 and collected hair samples concurrently. Methylmercury was measured in the full-length of each hair sample using gas chromatography inductively-coupled plasma-mass spectrometry. Multivariable linear regression estimated beta-coefficients and 95\% confidence intervals (Cls) for the effect of fish/whale consumption on hair-methylmercury concentrations.

Results: Among 101 participants who provided hair samples and diet data, the mean number of fish/whale species eaten was 3.5 (SD:1.9). The mean hair-methylmercury concentration was $0.60 \mu \mathrm{g} / \mathrm{g}$ (SD:0.47). Fish/whale consumption was positively associated with hair-methylmercury concentration, after adjusting for sex, hair length and use of permanent hair treatments. Hair-methylmercury concentrations among participants who consumed the most fish/whale in each season ranged from $0.30-0.50 \mu \mathrm{g} / \mathrm{g}$ higher than those who consumed $<1$ meal/week.

Conclusions: In this population of Canadian Arctic subsistence fishers, hair-methylmercury concentration increased with fish/whale consumption, but the maximum concentrations were below Health Canada's $6.0 \mu \mathrm{g} / \mathrm{g}$ threshold for safe exposure.
\end{abstract}

Keywords: Methylmercury, Fish consumption, Whale consumption, Canadian Arctic, Hair analysis

\footnotetext{
* Correspondence: emily.walker@ualberta.ca

${ }^{1}$ Faculty of Medicine and Dentistry, University of Alberta, Edmonton, Canada

${ }^{2}$ School of Public Health, University of Alberta, Edmonton, Alberta, Canada

Full list of author information is available at the end of the article
}

(c) The Author(s). 2020 Open Access This article is licensed under a Creative Commons Attribution 4.0 International License, which permits use, sharing, adaptation, distribution and reproduction in any medium or format, as long as you give appropriate credit to the original author(s) and the source, provide a link to the Creative Commons licence, and indicate if changes were made. The images or other third party material in this article are included in the article's Creative Commons licence, unless indicated otherwise in a credit line to the material. If material is not included in the article's Creative Commons licence and your intended use is not permitted by statutory regulation or exceeds the permitted use, you will need to obtain permission directly from the copyright holder. To view a copy of this licence, visit http://creativecommons.org/licenses/by/4.0/. The Creative Commons Public Domain Dedication waiver (http://creativecommons.org/publicdomain/zero/1.0/) applies to the data made available in this article, unless otherwise stated in a credit line to the data. 


\section{Background}

Mercury is a chemical element with the capacity to induce potent toxic effects in humans. Because of this, contamination of the environment with mercury compounds represents a substantial environmental health concern. For this reason, mercury has been the focus of a large body of research aimed at identifying the mechanisms through which it enters the environment, as well as pathways for human exposure and subsequent toxicological effects.

When elemental mercury finds its way into aquatic systems, some of it transforms into methylmercury (MeHg) [1-5]. As an organic compound, MeHg is lipophilic and mobile, with the capacity to enter the plasma membrane of cells and accumulate in the cytoplasm [1, 5]. This property has important implications for bioconcentration of $\mathrm{MeHg}$ in aquatic organisms and subsequent biomagnification in aquatic food chains [1-5]. $\mathrm{MeHg}$ contamination of aquatic ecosystems is considered the most abundant non-occupational source of human exposure to mercury $[1-4,6,7]$. The primary source of $\mathrm{MeHg}$ exposure in humans is consumption of fish or fish products and marine mammals, with larger, longer-living fish posing greater risk of exposure $[1-4,6$, 7]. The most heavily exposed human population groups include sport or subsistence fishers residing in Arctic communities [1-3, 8]. Arctic fish pose a disproportional threat due to greater emissions of elemental mercury in the northern hemisphere, changes to the global climate altering the mercury cycle, and more frequent consumption of species vulnerable to high levels of organic mercury contamination $[1-3,8]$. Additionally, sport and subsistence fishers do not benefit from regulatory measures that control the mercury content of commercially sold fish products.

Research on mercury exposure among Indigenous residents of the Canadian Arctic has typically focused on coastal populations that consume large amounts of marine mammals [9]. This is reasonable, given the greater capacity of these large species to accumulate mercury. Residents of inland communities in the western Canadian Arctic, however, are target audiences for public health messages about fish consumption, without concurrent exposure assessments [10, 11]. Our preliminary ethnographic research in western Canadian Arctic communities revealed residents' concerns about mercury accumulation in their bodies and how it relates to their fish and marine mammal consumption. In response, we conducted this research to analyze data collected from residents of inland communities in the Canadian Arctic to: characterize fish and marine mammal consumption patterns; biochemically measure the mercury level in hair samples to ascertain individual exposure to mercury; and estimate the effect of fish and marine mammal consumption, other dietary components and participant characteristics on the internal dose of mercury.

\section{Methods \\ Study design}

This mercury exposure project was an environmental health component of ongoing community-driven projects led by the Canadian North Helicobacter pylori (CANHelp) Working Group in western Canadian Arctic communities (www.canhelpworkinggroup.ca). The CANHelp Working Group formed during 2006-2008 in response to concerns raised by community leaders about $H$. pylori infection and gastric cancer risk. This research program is a collaborative effort, linking northern Canadian Indigenous communities, their health care providers and regional health authorities with investigators from multiple disciplines at the University of Alberta $[12,13]$. At the invitation of community leaders, crosssectional projects were established to describe the community health burden from $H$. pylori infection and associated disease and address community concerns. In each community, a planning committee made up of community members guided the conduct of each project and ensured that research activities were culturally appropriate and in keeping with community priorities.

\section{Person, place and time}

The mercury exposure project was conducted within three CANHelp Working Group community projects. The first of these projects launched in 2007 in the hamlet of Aklavik, Northwest Territories (NT) (2006 census population $=590, \sim 92 \%$ identifying as Gwich'in [Athabascan First Nation] or Inuvialuit [Inuit]) [14, 15]. Projects began in 2010 in Old Crow, Yukon (YT) (2011 census population $=245, \sim 85 \%$ identifying as Vuntut Gwich'in [16, 17], and in 2012 in Fort McPherson, NT (2011 census population $=844, \sim 90 \%$ Tetlit Gwich'in) [18]. Participation in the mercury exposure project was open to all residents of these three communities during September-November 2016. Recruitment activities involved radio announcements, social media posts, flyers on community message boards, and directly contacting participants of CANHelp Working Group projects for which current contact information was available.

\section{Informed consent}

All participants received an information sheet that outlined the study objectives, methods, information to be collected, benefits and potential risks of participation, and confidentiality protection measures. Following review of this document, each consenting participant filled out a consent form, confirming they had received enough information about the project and agreed to participate. Project information sheets and consent forms 
were reviewed and approved by the Research Ethics Board at the University of Alberta and have been published previously [19].

\section{Choice of tissue for biomarker analysis}

Evidence suggests that hair is the biological medium best suited for measuring MeHg exposure [1, 7, 20-32]. Hair from the scalp is a commonly selected matrix for biomonitoring of $\mathrm{MeHg}$ exposure, because $\mathrm{MeHg}$ accounts for approximately $80 \%$ of the total mercury found in hair and can be measured directly [1, 7, 20-32]. Practical advantages to collecting hair samples relative to urine and blood include: chemical stability; simple and noninvasive sampling; ease in storing, transporting and archiving specimens; and relatively low cost [21,33-36].

\section{Exposure time window}

Among healthy individuals, estimates of the scalp hair growth rate range from 0.6 to $3.36 \mathrm{~cm} /$ month, with an average of $1 \mathrm{~cm} /$ month [33-35]. The concentration of mercury measured in hair reflects exposure over the growth period of the sampled hair, which depends on hair length. According to input from local planning committees, residents of participating communities consume the greatest amount of aquatic species, on average, during the spring and summer seasons. For this reason, hair sample collection took place during the fall season (September-November).

\section{Hair sample collection}

Procedures for collecting hair samples were adapted from protocols outlined by the United States Centers for Disease Control (CDC) for use in the National Health and Nutrition Examination Survey (NHANES) [37]. We collected all hair samples from the occipital region of the scalp using stainless steel shears, obtaining a minimum of $120 \mathrm{mg}$ of hair from each participant to allow for duplication of the laboratory measurements for quality assurance/quality control (QA/QC) purposes. Given that hair length determines the exposure period represented in the strand, we also used a ruler to measure hair length (in $\mathrm{cm}$ ) before transferring samples into a zip-closable plastic bag and applying a label specifying the sample ID number, collection date, sample weight and hair length. Additionally, we recorded information on use of permanent hair treatments, including hair dye or permanent waves, and time since the most recent treatment.

\section{Laboratory analysis of samples}

The collected hair samples were analyzed by the University of Alberta Biogeochemical Analytical Service Laboratory (BASL). This lab has been accredited by the Canadian Association for Laboratory Accreditation
(CALA) as meeting ISO/IEC 17025 standards for the performance of specific tests. $\mathrm{MeHg}$ was measured in the full-length of each hair sample using gas chromatography inductively coupled plasma-mass spectrometry (GC-ICP-MS) [38, 39]. Quality control methods employed by the lab included the use of reference material 1AEA-085 for MeHg, total mercury and other trace elements in hair. Single point calibration was applied, and the calibration standard was analyzed in 4 replicates. The relative standard deviation for the ratio of $\mathrm{Hg}$ isotope 201:202 was considered acceptable if the value was less than $5 \%$. If the value was greater than $5 \%$, the calibration was repeated. Instrument and method blanks and a second source reference material were also used to monitor contamination with $\mathrm{MeHg}$, accuracy and instrumental drift during analysis. These were incorporated into the analysis at a frequency of 1 per batch of approximately 30 samples. The instrument was recalibrated if the second source reference material measurements were outside of the $80-120 \%$ recovery range. Additionally, water samples were spiked with a known quantity of enriched $\mathrm{MeHg}$ isotope $\left(\mathrm{CH}_{3}{ }^{201} \mathrm{Hg}\right)$ as an internal standard. Finally, laboratory duplicates were performed at a frequency of 1 per 5 samples. For added quality assurance, we divided approximately $10 \%$ of the samples into duplicates and submitted them to the lab as separate individuals. Lab personnel were blinded to all participant characteristics, including age, sex and the amount and types of aquatic species consumed.

\section{Fish and marine mammal consumption data}

We designed a population-appropriate Food Frequency Questionnaire (FFQ) focused on fish and marine mammal consumption in the past year for this study (Supplemental File 1). Community input guided the selection of included fish species and incorporation of familiar names and descriptions for locally harvested fish, to ensure respondents had a clear understanding of each FFQ item. Planning committee members identified Beluga Whale (D. leucas) as the only regularly consumed marine mammal. The FFQ measured consumption frequencies as average number of times each type of fish or whale was consumed per week (we will refer to food consumption events as "meals"). The FFQ did not include portion size to reduce the burden on participants and because validation studies have shown that attempting to ascertain portion size does not appreciably improve overall characterization of diet, because most people have poor recall of portion sizes [40]. To capture seasonal variability in consumption, the FFQ asked respondents to specify the time of year in which they typically harvest each aquatic species they reported consuming. The FFQ then asked respondents the typical number of meals per week of each species during the 
time of year they are harvested. Since it is common for community members to preserve harvested fish by drying, freezing or smoking the meat, the FFQ asked respondents to report the frequency of consuming each species during other parts of the year. Given the potential for preparation methods to alter the bioavailability of mercury in consumed fish, the FFQ also asked participants to specify how they typically prepared each type of fish/whale for eating and the parts they consumed [41]. Most participants were able to identify the specific species they consumed; pictures were available for those who were unsure. The potential for the overall composition of an individual's diet and intake of specific nutrients to directly or indirectly influence the toxicokinetic properties of $\mathrm{MeHg}$ has been described in the scientific literature [42]. For this reason, the FFQ collected data on other dietary components, including average weekly intake of: fruit, fresh fruit juice, raw and cooked vegetables, fresh or packaged milk, and yogurt.

\section{Exposure definition}

Fish/whale consumption constituted the source of mercury exposure examined for this analysis. The structure of the FFQ permitted the creation of separate variables representing the usual frequency of consuming each reported species in units of average meals per week in each of the four seasons. We estimated the average number of fish/whale meals/week across seasons. The number of seasons incorporated in the average was determined by each participant's hair length, with $3 \mathrm{~cm}$ corresponding to a single season.

\section{Outcome definition}

The outcome for this analysis was the MeHg concentration measured in hair samples in units of $\mu \mathrm{g} / \mathrm{g}$ on a continuous scale. Guidelines generated by Health Canada for interpreting the degree of risk associated with hairmercury levels provide perspective for interpreting values [43]: hair mercury concentrations $\leq 6 \mu \mathrm{g} / \mathrm{g}$ are considered acceptable for adult males and females who are not pregnant or breastfeeding [43]; among children under 12 years and women who are pregnant, breastfeeding or of reproductive age, concentrations $\leq 2 \mu \mathrm{g} / \mathrm{g}$ are considered acceptable [43].

\section{Statistical analysis}

The goal of the statistical analysis was to estimate the association between fish/whale meals per week and hair$\mathrm{MeHg}$ concentration in the study population. We constructed a multivariable linear regression model to estimate beta coefficients and 95\% confidence intervals (CIs) as measures of the association between characteristics of interest and hair- $\mathrm{MeHg}$ concentration $(\mu \mathrm{g} / \mathrm{g})$. To confirm whether fish/whale consumption frequency could be modeled as a continuous variable, the linearity of the relationship of the continuous form of this variable to hair-MeHg concentration was assessed using a lowess plot (bandwidth: 0.80). Visual inspection of the lowess plots representing the locally weighted regression of $\mathrm{MeHg}$ concentration on exposure variables for each season showed that the relationships were not sufficiently linear to justify modeling exposures as continuous variables. Given lack of linearity, the fish/whale consumption variable was converted to a categorical format. A categorical format was the chosen alternative to modeling fish/whale consumption as continuous as a widely accepted approach that results in effect estimates that are easy to interpret, relative to transformations of continuous values. When possible, category boundaries were defined so that there was no more than a two-fold increase in number of servings within a category [40]. The purpose of this was to generate categories within which the effect of interest did not vary substantially [40, 44].

\section{Variable selection}

We used purposeful selection, as proposed by Hosmer and Lemeshow (2000), to identify the best set of adjustment variables [45]. This method follows a change-inestimate approach, with variable selection decisions based on the extent to which each potential covariate influences the magnitude of exposure effects of interest: All potential covariates were included in a multivariable model and subsequently removed one at a time. If the coefficient of any independent variable changed by $\geq 10 \%$ with the removal of a given covariate, the removed variable was included in the final model [45]. Variables considered for inclusion in the model were: age, sex, community, use of permanent hair treatments, the proportion of consumed fish/whale species harvested from the ocean or local rivers, the proportion of consumed species usually prepared by cooking (versus eaten raw, dried or smoked), and other dietary frequencies, including fruits and vegetables, dairy products or regular use of dietary supplements.

\section{Bias analysis}

Given the potential for $\mathrm{MeHg}$ measurement error to produce outcome misclassification, we conducted a quantitative bias analysis using the variation in measured hair-MeHg concentrations of duplicated samples. We calculated the percent change between duplicate analyses of the same participant's hair. For participants with more than 2 samples analyzed, we used the 2 values that differed the most for the percent change calculation. For participants with more than 2 measurements, the largest difference between measured concentrations was used. To quantify the extent to which measurement error 
influenced inferences drawn from this analysis, we adjusted the initially measured $\mathrm{MeHg}$ values in two ways. First the overall mean percent change and the proportion of the repeated measurements that increased or decreased in value were used to estimate the magnitude of measurement error and frequency of change in either direction in the entire study population. Second, the mean percent change between repeated measurements and the proportion that increased or decreased were stratified by participant characteristics to apply stratumspecific estimates of the magnitude and direction of measurement error to corresponding subsets of participants, selecting at random the participants assigned increasing or decreasing $\mathrm{MeHg}$ concentrations. All analyses were repeated using the adjusted $\mathrm{MeHg}$ concentrations as outcome variables.

\section{Results}

\section{Participant characteristics}

In the three communities combined, 101 participants provided hair samples and diet data (42 from Aklavik, NT; 32 from Old Crow, YT; and 24 from Fort McPherson, NT). The mean age was 52 years (SD: 15.7; Range: 10-86). Participants were nearly all Indigenous, predominantly identifying as either Gwich'in $(60 \% ; 60 / 101)$ or Inuvialuit $(30 \% ; 30 / 101)$. A few participants were of European descent $(6 \% ; 6 / 101)$ but had been residing in the community for at least 5 years. The study population was disproportionately female (63\%; 64/101); none were pregnant or breastfeeding at the time of data collection. Assuming an average growth rate of $1 \mathrm{~cm} /$ month, the exposure periods represented in the collected hair samples ranged from approximately 3 weeks to almost 9 years (median: 1.1 year; IQR: 2.1 years).

\section{Patterns of fish/whale consumption}

Almost all participants (96\%; 97/101) reported eating fish/whale in the past 12 months. The data obtained from the fish-focused FFQ was consistent with input from community planning committees, which identified the summer as the season when community members consume fish/whale most frequently (Fig. 1). However, there was considerable variation by species and community (Supplementary File 2, Table 1). The fish species consumed by the largest proportion of participants was Broad Whitefish (C.nasus) (83\%), followed by Inconnu (S.nelma) (42\%) and Dolly Varden (S.malma) (33\%). A large proportion of participants also ate Beluga Whale (D.leucas) (42\%); 71\% (30/42) of those who reported eating Beluga Whale in the past 12 months were from Aklavik, NT, the community with the largest proportion of Inuit residents. Table 2 shows the five most frequent species consumed $\geq 1$ time/week by community. The mean number of different species eaten by participants was 3.5 (SD: 1.9; Range: 0-9). On average, participants reported harvesting most of the species they consumed from local rivers, followed by the ocean and nearby lakes. The distribution of harvesting sites, averaging across species was: rivers, 66.7\% (SD: 32.9\%; Range: 0100); the ocean, $21.7 \%$ (SD: 27.4; Range: 0-100); and lakes $1.8 \%$ (SD: 8.2; Range: 0-50). The proportion purchased from the store, averaging across species, was 2.0\% (SD: 7.6; Range: 0-33).

\section{MeHg concentrations}

Among participants from all communities combined, the mean concentration of $\mathrm{MeHg}$ in hair samples was $0.60 \mu \mathrm{g} / \mathrm{g}$ (SD: 0.47; Range: 0.059-2.07). This varied slightly across communities, with mean values from
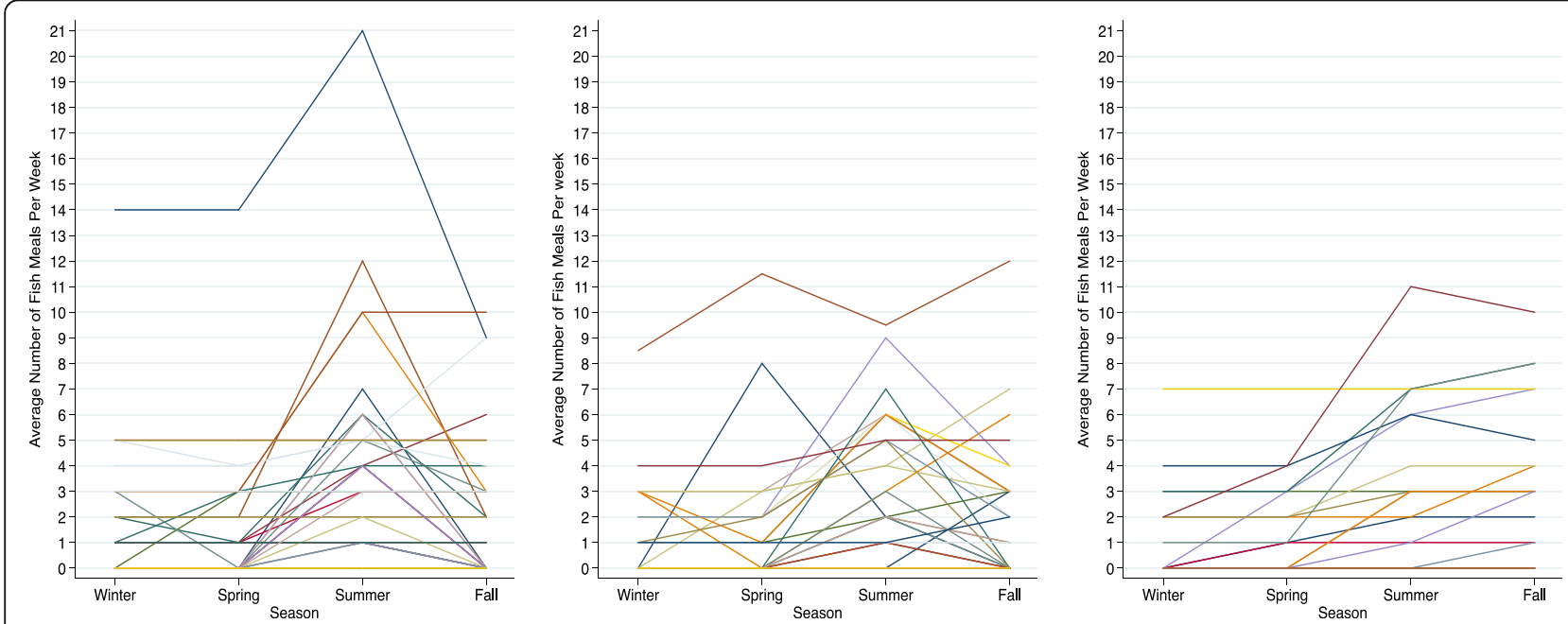

Fig. 1 Average number of fish/whale meals per week by season among participants from Aklavik, Northwest Territories (left; $n=45$ ), Old Crow, Yukon (middle; $n=32$ ) and Fort McPherson, Northwest Territories (Right; $n=24)$, 2016. Each Line represents an individual 
Table 1 Five most frequent aquatic species consumed at least once per week by season and community, 101 western Canadian Arctic residents, 2016

\begin{tabular}{|c|c|c|c|c|c|c|c|c|c|}
\hline \multirow[t]{2}{*}{ Season } & \multicolumn{3}{|l|}{$\begin{array}{l}\text { Aklavik, NT } \\
(n=45)\end{array}$} & \multicolumn{3}{|l|}{$\begin{array}{l}\text { Old Crow, YT } \\
(n=32)\end{array}$} & \multicolumn{3}{|c|}{$\begin{array}{l}\text { Fort McPherson, NT } \\
(n=24)\end{array}$} \\
\hline & Species & $n$ & $\%$ & Species & $\mathrm{n}$ & $\%$ & Species & $\mathrm{n}$ & $\%$ \\
\hline Winter & $\begin{array}{l}\text { S. nelma } \\
\text { C. nasus } \\
\text { D. leucas } \\
\text { S. malma } \\
\text { C. autumnalis }\end{array}$ & $\begin{array}{l}9 \\
8 \\
7 \\
5 \\
4\end{array}$ & $\begin{array}{l}20 \\
18 \\
16 \\
11 \\
9\end{array}$ & $\begin{array}{l}\text { C. nasus } \\
\text { O. tshawytscha } \\
\text { C. clupeaformis } \\
\text { O. kisutch } \\
\text { T. arcticas }\end{array}$ & $\begin{array}{l}8 \\
6 \\
3 \\
2 \\
2\end{array}$ & $\begin{array}{l}25 \\
19 \\
9 \\
6 \\
6\end{array}$ & $\begin{array}{l}\text { C. nasus } \\
\text { S. nelma }\end{array}$ & $\begin{array}{l}9 \\
5\end{array}$ & $\begin{array}{l}38 \\
21\end{array}$ \\
\hline Spring & $\begin{array}{l}\text { S. nelma } \\
\text { D. leucas } \\
\text { C. nasus } \\
\text { S. malma } \\
\text { C. autumnalis }\end{array}$ & $\begin{array}{l}8 \\
8 \\
7 \\
5 \\
4\end{array}$ & $\begin{array}{l}18 \\
18 \\
16 \\
11 \\
9\end{array}$ & $\begin{array}{l}\text { C. nasus } \\
\text { O. tshawytscha } \\
\text { C. clupeaformis } \\
\text { O. kisutch } \\
\text { T. arcticas }\end{array}$ & $\begin{array}{l}8 \\
7 \\
4 \\
2 \\
2\end{array}$ & $\begin{array}{l}25 \\
22 \\
13 \\
6 \\
6\end{array}$ & $\begin{array}{l}\text { C. nasus } \\
\text { S. nelma }\end{array}$ & $\begin{array}{l}11 \\
6\end{array}$ & $\begin{array}{l}46 \\
25\end{array}$ \\
\hline Summer & $\begin{array}{l}\text { D. leucas } \\
\text { S. malma } \\
\text { C. nasus } \\
\text { C. autumnalis } \\
\text { S. nelma }\end{array}$ & $\begin{array}{l}17 \\
14 \\
14 \\
13 \\
10\end{array}$ & $\begin{array}{l}38 \\
31 \\
31 \\
29 \\
22\end{array}$ & $\begin{array}{l}\text { O. tshawytscha } \\
\text { C. nasus } \\
\text { O. keta } \\
\text { S. aplinus } \\
\text { O. kisutch } \\
\text { T. arcticas }\end{array}$ & $\begin{array}{l}20 \\
9 \\
3 \\
2 \\
2 \\
2\end{array}$ & $\begin{array}{l}63 \\
28 \\
9 \\
6 \\
6 \\
6\end{array}$ & $\begin{array}{l}\text { C. nasus } \\
\text { S. nelma } \\
\text { S. aplinus } \\
\text { D. leucas }\end{array}$ & $\begin{array}{l}14 \\
10 \\
1 \\
1\end{array}$ & $\begin{array}{l}58 \\
42 \\
4 \\
4\end{array}$ \\
\hline Fall & $\begin{array}{l}\text { C. nasus } \\
\text { S. nelma } \\
\text { D. leucas } \\
\text { S. malma } \\
\text { C. autumnalis }\end{array}$ & $\begin{array}{l}9 \\
8 \\
6 \\
6 \\
4\end{array}$ & $\begin{array}{l}20 \\
18 \\
13 \\
13 \\
9\end{array}$ & $\begin{array}{l}\text { C. nasus } \\
\text { O. tshawytscha } \\
\text { O. keta } \\
\text { L. lota } \\
\text { C. clupeaformis } \\
\text { T. arcticas }\end{array}$ & $\begin{array}{l}9 \\
7 \\
5 \\
4 \\
3 \\
3\end{array}$ & $\begin{array}{l}28 \\
22 \\
16 \\
13 \\
9 \\
9\end{array}$ & $\begin{array}{l}\text { C. nasus } \\
\text { S. nelma } \\
\text { L. Lota } \\
\text { S. aplinus } \\
\text { S. malma }\end{array}$ & $\begin{array}{l}15 \\
8 \\
5 \\
1 \\
1\end{array}$ & $\begin{array}{l}63 \\
33 \\
21 \\
4 \\
4\end{array}$ \\
\hline
\end{tabular}

Aklavik NT, Old Crow YT and Fort McPherson NT of $0.51 \mu \mathrm{g} / \mathrm{g}$ (SD: 0.44; Range: 0.06-2.07), $0.54 \mu \mathrm{g} / \mathrm{g}$ (SD: 0.35; Range: $0.11-1.51)$ and $0.84 \mu \mathrm{g} / \mathrm{g}$ (SD: 0.58; Range: 0.06-1.90), respectively (Fig. 2). Mean hair mercury levels $(\mu \mathrm{g} / \mathrm{g}) \pm$ SD stratified by population characteristics are shown in Table 22. No participants had hair mercury levels that exceeded the exposure maximum defined by Health Canada.

\section{Regression results}

Because data were insufficient for estimation of speciesspecific effects on hair mercury levels, this analysis was limited to effects of total fish/whale consumption. Model building procedures yielded the following set of adjustment variables for fish/whale consumption in each season: sex, use of hair dye or other permanent hair treatments, and the proportion of fish/whale meals usually prepared by cooking. There was evidence of statistical interaction between fish/whale consumption and use of permanent hair treatments. Table 3 shows multivariable regression results. Compared to participants who consumed $<1$ fish/whale meal/week, hair-MeHg concentration was higher on average among participants who consumed fish/whale more often. A positive doseresponse observed in unadjusted beta-coefficients was less striking in the multivariable model, which showed that compared to the referent of $<1 \mathrm{meal} /$ week, the effect of consuming 3-4 meals/week on hair-MeHg concentration was modestly larger than the effect of consuming $\geq 5$ meals/week (Table 3 The confidence intervals of the adjusted effect estimates for the highest 2 levels of fish/whale consumption (3-4 and $\geq 5$ meals/ week) had lower limits well above the adjusted effect estimate for 1-2 meals/week, however, indicating a clear increase in hair- $\mathrm{MeHg}$ concentration among those consuming 3 or more fish/whale meals/week relative to those consuming $<1 \mathrm{meal} /$ week. Assessment of interaction between fish/whale consumption and permanent hair treatment use showed lower hair-MeHg concentrations among participants who reported using permanent hair treatments, relative to those who did not (Fig. 3). Additionally, there was no effect of increasing fish/whale consumption on hair- $\mathrm{MeHg}$ concentration for those who used permanent hair treatments and consumed less than 5 meals/week (Fig. 3). Conversely, participants who did not report use of permanent hair treatments had higher hair- $\mathrm{MeHg}$ concentrations if they consumed more than $1 \mathrm{fish} / \mathrm{meal}$ per week relative to those who consumed $<1$ meal/week (Fig. 3).

\section{Dietary covariates}

Few participants reported consuming more than 2 daily servings of fruits and vegetables (Table 2). Conversely, of 101 participants, 45 reported consuming dairy products more than once per day and 40 reported regular use of dietary supplements (vitamins, calcium, fish oil, omega-3 and fibre). Inspection of distributions of hair- $\mathrm{MeHg}$ concentrations across categories of dietary components does not reveal clear patterns of association between intake frequencies and 
Table 2 Distribution of participant characteristics and stratum-specific mean MeHg concentrations ( $\mu \mathrm{g} / \mathrm{g}$ ) by community, 101 western Canadian Arctic residents, 2016

\begin{tabular}{|c|c|c|c|c|c|c|c|c|}
\hline \multirow[t]{2}{*}{$\begin{array}{l}\text { Participant } \\
\text { Characteristics }\end{array}$} & \multicolumn{2}{|c|}{$\begin{array}{l}\text { Total } \\
(\boldsymbol{n}=101)\end{array}$} & \multicolumn{2}{|c|}{$\begin{array}{l}\text { Aklavik, NT } \\
(n=45)\end{array}$} & \multicolumn{2}{|c|}{$\begin{array}{l}\text { Old Crow, YT } \\
(n=32)\end{array}$} & \multicolumn{2}{|c|}{$\begin{array}{l}\text { Fort McPherson, NT } \\
(\mathrm{n}=24)\end{array}$} \\
\hline & $\mathrm{n}(\%)$ & Mean \pm SD & $\mathrm{n}(\%)$ & Mean \pm SD & $\mathrm{n}(\%)$ & Mean \pm SD & $\mathrm{n}(\%)$ & Mean \pm SD \\
\hline \multicolumn{9}{|c|}{ Demographic Characteristics } \\
\hline \multicolumn{9}{|l|}{ Age } \\
\hline $10-30$ years & $9(9)$ & $0.26 \pm 0.21$ & $5(11)$ & $0.17 \pm 0.08$ & $4(12.5)$ & $0.37 \pm 0.27$ & $0(0)$ & - \\
\hline $31-40$ years & $15(15)$ & $0.45 \pm 0.60$ & $8(18)$ & $0.50 \pm 0.70$ & $4(12.5)$ & $0.53 \pm 0.66$ & $3(12.5)$ & $0.20 \pm 0.23$ \\
\hline $41-50$ years & $14(14)$ & $0.49 \pm 0.34$ & $8(18)$ & $0.41 \pm 0.35$ & $4(12.5)$ & $0.58 \pm 0.35$ & $2(8)$ & $0.59 \pm 0.44$ \\
\hline $52-60$ years & $35(35)$ & $0.79 \pm 0.52$ & $14(31)$ & $0.60 \pm 0.35$ & $7(22)$ & $0.57 \pm 0.44$ & $14(58)$ & $1.09 \pm 0.57$ \\
\hline $61-70$ years & $17(17)$ & $0.57 \pm 0.31$ & $6(13)$ & $0.78 \pm 0.43$ & $9(28)$ & $0.47 \pm 0.16$ & $2(8)$ & $0.42 \pm 0.00$ \\
\hline $71-86$ years & $11(11)$ & $0.64 \pm 0.39$ & $4(9)$ & $0.42 \pm 0.36$ & $4(12.5)$ & $0.78 \pm 0.27$ & $3(12.5)$ & $0.75 \pm 0.56$ \\
\hline \multicolumn{9}{|l|}{ Sex } \\
\hline Male & $37(37)$ & $0.74 \pm 0.51$ & $13(29)$ & $0.53 \pm 0.46$ & $17(53)$ & $0.68 \pm 0.40$ & $7(29)$ & $1.28 \pm 0.49$ \\
\hline Female & $64(63)$ & $0.51 \pm 0.42$ & $32(71)$ & $0.50 \pm 0.43$ & $15(47)$ & $0.38 \pm 0.20$ & $17(71)$ & $0.66 \pm 0.52$ \\
\hline \multicolumn{9}{|l|}{ Hair Treatments } \\
\hline No & $70(69)$ & $0.64 \pm 0.49$ & $33(73)$ & $0.48 \pm 0.37$ & $20(62.5)$ & $0.62 \pm 0.40$ & $17(71)$ & $0.95 \pm 0.64$ \\
\hline Yes & $31(31)$ & $0.51 \pm 0.42$ & $12(27)$ & $0.59 \pm 0.59$ & $12(37.5)$ & $0.40 \pm 0.21$ & $7(29)$ & $0.58 \pm 0.32$ \\
\hline \multicolumn{9}{|c|}{ Fish/Whale Consumption } \\
\hline$<1$ meal/week & $38(38)$ & $0.42 \pm 0.37$ & $18(40)$ & $0.38 \pm 0.34$ & $11(34)$ & $0.38 \pm 0.28$ & $9(38)$ & $0.55 \pm 0.52$ \\
\hline 1-2 meals/week & $21(21)$ & $0.57 \pm 0.48$ & $9(20)$ & $0.43 \pm 0.35$ & $7(22)$ & $0.42 \pm 0.32$ & $5(21)$ & $1.04 \pm 0.62$ \\
\hline 3-4 meals/week & $22(22)$ & $0.71 \pm 0.48$ & $9(20)$ & $0.57 \pm 0.48$ & $9(28)$ & $0.69 \pm 0.38$ & $4(17)$ & $1.05 \pm 0.64$ \\
\hline$\geq 5$ meals/week & $20(20)$ & $0.84 \pm 0.50$ & $9(20)$ & $0.80 \pm 0.55$ & $5(16)$ & $0.77 \pm 0.37$ & $6(25)$ & $0.96 \pm 0.58$ \\
\hline \multicolumn{9}{|c|}{ Other Dietary Components } \\
\hline \multicolumn{9}{|l|}{ Fruit \& Vegetables } \\
\hline 1-3 times/week & $20(20)$ & $0.69 \pm 0.52$ & $11(24)$ & $0.53 \pm 0.42$ & $5(16)$ & $0.48 \pm 0.18$ & $4(17)$ & $1.39 \pm 0.49$ \\
\hline 4-7 times/week & $27(27)$ & $0.61 \pm 0.51$ & $12(27)$ & $0.49 \pm 0.39$ & $5(16)$ & $0.51 \pm 0.44$ & $10(42)$ & $0.81 \pm 0.64$ \\
\hline $\begin{aligned}> & 1 \text { time/day; } \\
& <2 \text { times/day }\end{aligned}$ & $30(30)$ & $0.69 \pm 0.52$ & $13(29)$ & $0.69 \pm 0.52$ & $11(34)$ & $0.69 \pm 0.52$ & $6(25)$ & $0.69 \pm 0.52$ \\
\hline$\geq 2$ times/day & $24(24)$ & $0.59 \pm 0.47$ & $9(20)$ & $0.74 \pm 0.63$ & $11(34)$ & $0.45 \pm 0.27$ & $4(17)$ & $0.64 \pm 0.51$ \\
\hline \multicolumn{9}{|l|}{ Dairy } \\
\hline$\leq 1$ time/week & $29(29)$ & $0.59 \pm 0.47$ & $13(29)$ & $0.74 \pm 0.63$ & $10(31)$ & $0.45 \pm 0.27$ & $6(25)$ & $0.64 \pm 0.51$ \\
\hline 2-4 times/week & $14(14)$ & $0.61 \pm 0.50$ & $9(20)$ & $0.53 \pm 0.40$ & $1(3)$ & $0.50 \pm 0.43$ & $4(17)$ & $0.96 \pm 0.72$ \\
\hline 5-7 times/week & $13(13)$ & $0.67 \pm 0.42$ & $9(20)$ & $0.59 \pm 0.40$ & $2(6)$ & $0.59 \pm 0.00$ & $2(8)$ & $0.88 \pm 0.50$ \\
\hline$>1$ time/day & $45(45)$ & $0.25 \pm 0.16$ & $14(31)$ & $0.23 \pm 0.13$ & $19(59)$ & $0.37 \pm 0.25$ & $12(50)$ & $0.23 \pm 0.24$ \\
\hline \multicolumn{9}{|c|}{ Uses Dietary Supplements } \\
\hline No & $62(61)$ & $0.67 \pm 0.49$ & $33(73)$ & $0.62 \pm 0.56$ & $19(59)$ & $0.57 \pm 0.34$ & $10(42)$ & $0.86 \pm 0.57$ \\
\hline Yes & $39(39)$ & $0.58 \pm 0.47$ & $12(27)$ & $0.46 \pm 0.36$ & $13(41)$ & $0.59 \pm 0.44$ & $14(58)$ & $0.94 \pm 0.66$ \\
\hline
\end{tabular}

hair-MeHg levels. This is consistent with results of the model building procedures, which did not identify the selected dietary factors as important confounders or effect-measure modifiers of the relationship under investigation in the study population. It should be noted, however, that the observed lack of association could reflect insufficient data for precise estimation of effects.

\section{Bias analysis}

Of the 22 samples selected at random in the lab for duplicate $\mathrm{MeHg}$ concentration measurement, 4 came from individuals who were among the 10 we selected at random as blind duplicates, yielding 28 participants with duplicate measurements; the median percent change in $\mathrm{MeHg}$ concentration between measurements was $14.67 \%$ (IQR: 10.75$)$ with $36 \%(10 / 28)$ having second values that 


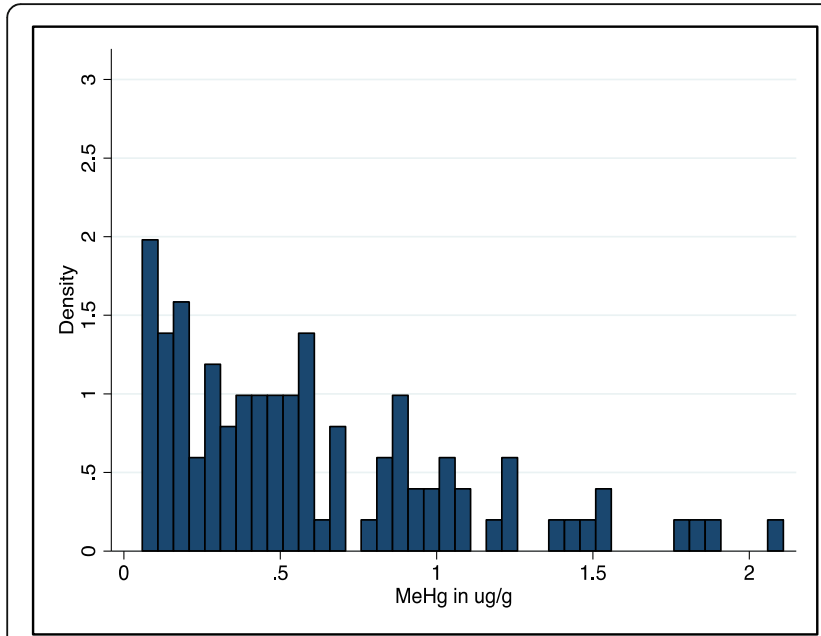

Total Sample $(n=101)$

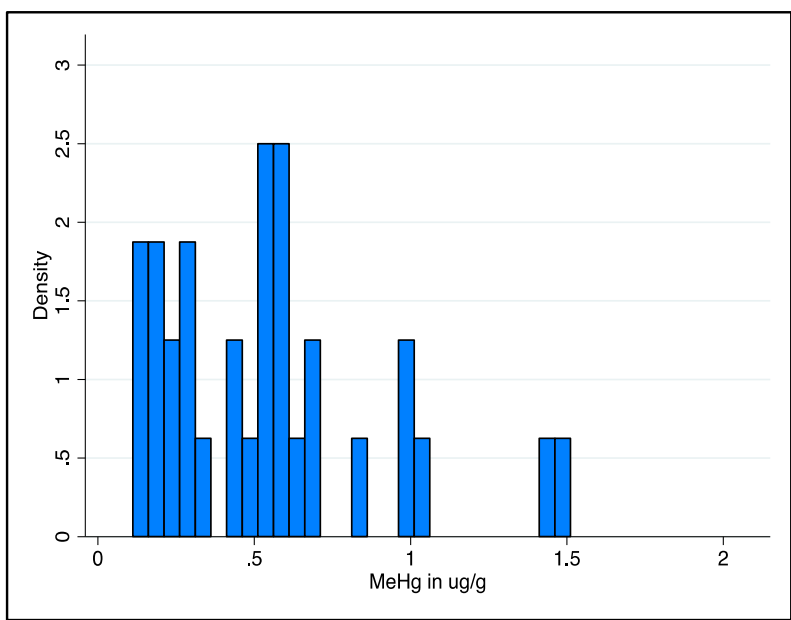

Old Crow, YT ( $n=32)$

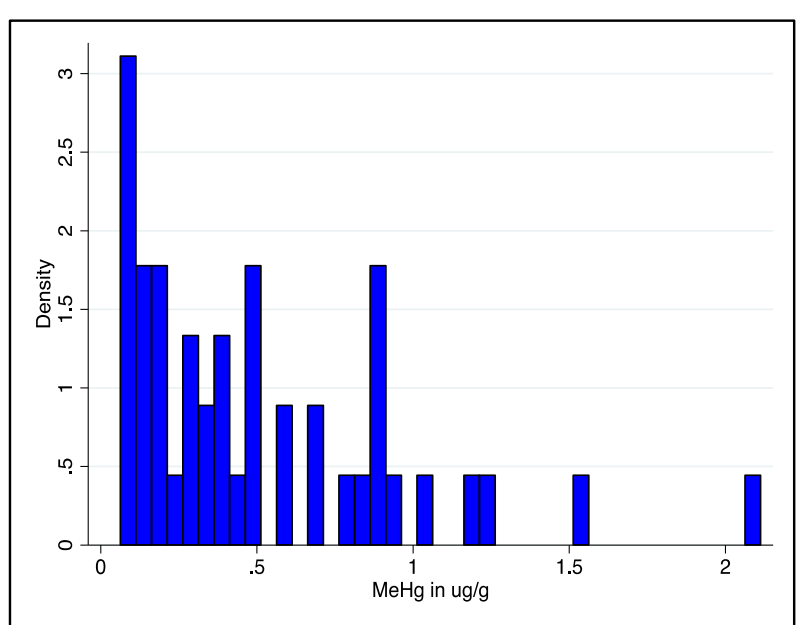

Aklavik, NWT $(n=42)$

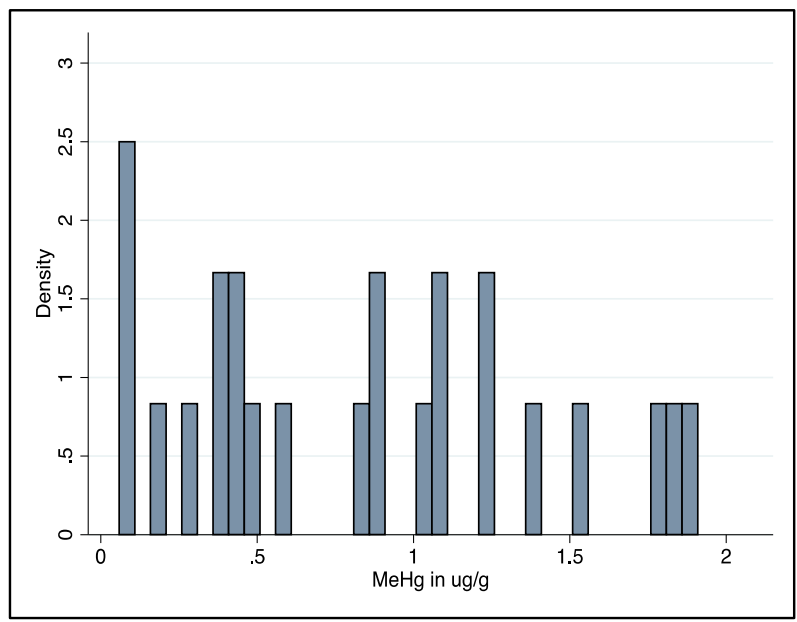

Fort McPherson, NWT $(n=24)$

Fig. 2 Distribution of MeHg measurements $(\mu \mathrm{g} / \mathrm{g})$ in hair samples among 101 western Canadian Arctic residents by community, 2016

were higher than the initial value. The maximum percent change of $159 \%$ corresponded to a woman with hair that had been dyed 1 month before sample collection. Excluding this extreme outlier, the mean percent change in $\mathrm{MeHg}$ concentration between measurements was 15.8\% (SD: 9.95; Range: 3.3-43.8). We performed a bias analysis using two distinct adjustments to hair-MeHg values based on variation in the duplicate measurements. Adjusted $\mathrm{MeHg}$ Measurement 1 did not stratify on hair treatment status while Adjusted $\mathrm{MeHg}$ Measurement 2 did (see Table 4); means of the adjusted hair-MeHg values were $0.58 \mu \mathrm{g} / \mathrm{g}$ (SD: 0.47; Range: 0.05-2.05) for Adjustment 1 and $0.57 \mu \mathrm{g} / \mathrm{g}$ (SD: 0.50; Range: 0.05-2.87) for Adjustment 2, both slightly lower than the unadjusted mean of $0.60 \mu \mathrm{g} / \mathrm{g}$ (SD: 0.47; Range: 0.0592.07). Under each of these scenarios, all participants remained at levels below those thought to pose serious health risks. Table 4 compares results from multivariable regression models using the originally measured $\mathrm{MeHg}$ concentrations to results of models using values adjusted for measurement error. These comparisons show that laboratory error in measurement of hair- $\mathrm{MeHg}$ is not likely to have impacted inferences drawn from this analysis; regardless of measurement adjustments, confidence intervals of effect estimates still indicate that participants at the highest 2 fish/whale consumption levels have clearly higher average hair $\mathrm{HeMg}$ concentrations than those at the reference level.

\section{Discussion}

In this study of residents of Western Canadian Arctic communities, hair-MeHg concentration increased with fish/whale consumption, but observed concentrations were all well below levels expected to cause serious health effects according to Canadian government standards [43]. In our analyses, the effect of consuming more 
Table 3 Multiple regression of hair MeHg concentrations $(\mu \mathrm{g} / \mathrm{g})$ on fish/whale consumption frequency, 101 western Canadian Arctic residents, 2016

\begin{tabular}{|c|c|c|c|c|c|}
\hline & & \multicolumn{2}{|c|}{ Unadjusted } & \multicolumn{2}{|c|}{ Adjusted $\Phi$} \\
\hline & & $\bar{\beta}$ & $95 \% \mathrm{Cl}$ & $\bar{\beta}$ & $95 \% \mathrm{Cl}$ \\
\hline \multicolumn{6}{|l|}{ Sex } \\
\hline Female & & Reference & & Reference & \\
\hline Male & & 0.227 & $0.040,0.414$ & 0.167 & $-0.014,0.347$ \\
\hline \multicolumn{6}{|l|}{ Dye or Perm } \\
\hline No & & Reference & & Reference & \\
\hline Yes & & -0.124 & $-0.324,0.075$ & 0.031 & $-0.292,0.355$ \\
\hline \multicolumn{6}{|l|}{ Community } \\
\hline Aklavik, NWT & & Reference & & Reference & \\
\hline Old Crow, YT & & 0.027 & $-0.180,0.234$ & -0.125 & $-0.334,0.085$ \\
\hline Fort McPherson, NWT & & 0.327 & $0.101,0.554$ & 0.249 & $0.039,0.459$ \\
\hline Proportion Cooked & & 0.004 & $0.0001,0.0075$ & 0.004 & $-0.00006,0.007$ \\
\hline \multicolumn{6}{|l|}{ Fish/Whale Consumption } \\
\hline$<1$ meal/week & & Reference & & Reference & \\
\hline 1-2 meals/week & & 0.142 & $-0.088,0.372$ & 0.142 & $-0.106,0.391$ \\
\hline 3-4 meals/week & & 0.337 & $0.092,0.583$ & 0.542 & $0.235,0.849$ \\
\hline$\geq 5$ meals/week & & 0.422 & $0.181,0.663$ & 0.419 & $0.152,0.689$ \\
\hline \multicolumn{6}{|c|}{ Interaction between Fish/Whale Consumption and Use of Permanent Hair Treatments } \\
\hline Fish/Whale Consumption & Dye/Perm & & & & \\
\hline \multirow[t]{2}{*}{ 1-2 meals/week } & No & & & Reference & \\
\hline & Yes & & & -0.112 & $-0.607,0.382$ \\
\hline \multirow[t]{2}{*}{ 3-4 meals/week } & No & & & Reference & \\
\hline & Yes & & & -0.588 & $-1.083,-0.094$ \\
\hline \multirow[t]{2}{*}{$\geq 5$ meals/week } & No & & & Reference & \\
\hline & Yes & & & -0.192 & $-0.693,0.309$ \\
\hline
\end{tabular}

fish/whale meals/week was smaller among participants who used permanent hair treatments relative to those who did not; however, data were insufficient for precise estimation of this effect.

Our findings are consistent with the literature pertaining to the relationship between intake of aquatic species and internal dose of mercury as measured in hair [22, 28, 46-60]. Among 66 studies of this relationship identified by systematic review, 44 (67\%) showed that increasing fish consumption was associated with increasing hair mercury concentrations [19]. Additionally, our description of the shape of this relationship as nonlinear was supported by the systematic review, which showed that the shape and strength of the relationship varied across populations. As well, our identification of factors associated with the reliability of hair-mercury measurements are consistent with the literature. Specifically, our observation that the use of dyes and other permanent hair treatments were associated with the greatest percentchange between repeated measurements is consistent with evidence suggesting that cuticle damage impacts the retention of compounds and treatment-induced damage can impact strands within the same region of the head to different degrees [61]. It should, however, be noted that our study only had 6 participants who used permanent hair treatments for whom measurements were repeated.

Because there was a wide range of hair lengths among the collected samples (median of estimated growth periods: 1.1 years; IQR: 2.1 years) and hair growth rates vary across individuals, the exposure time windows represented in hair samples cannot be classified perfectly $[34,62]$. Although we incorporated hair length in the exposure definition, this may not have adequately controlled for seasonal variations in exposure to $\mathrm{MeHg}$. Since the hair- $\mathrm{MeHg}$ measurement was an average concentration across the whole strand, the measured concentration for participants who consume large amounts of fish in only one season and have hair that captures exposure in multiple seasons would not reflect their peak 


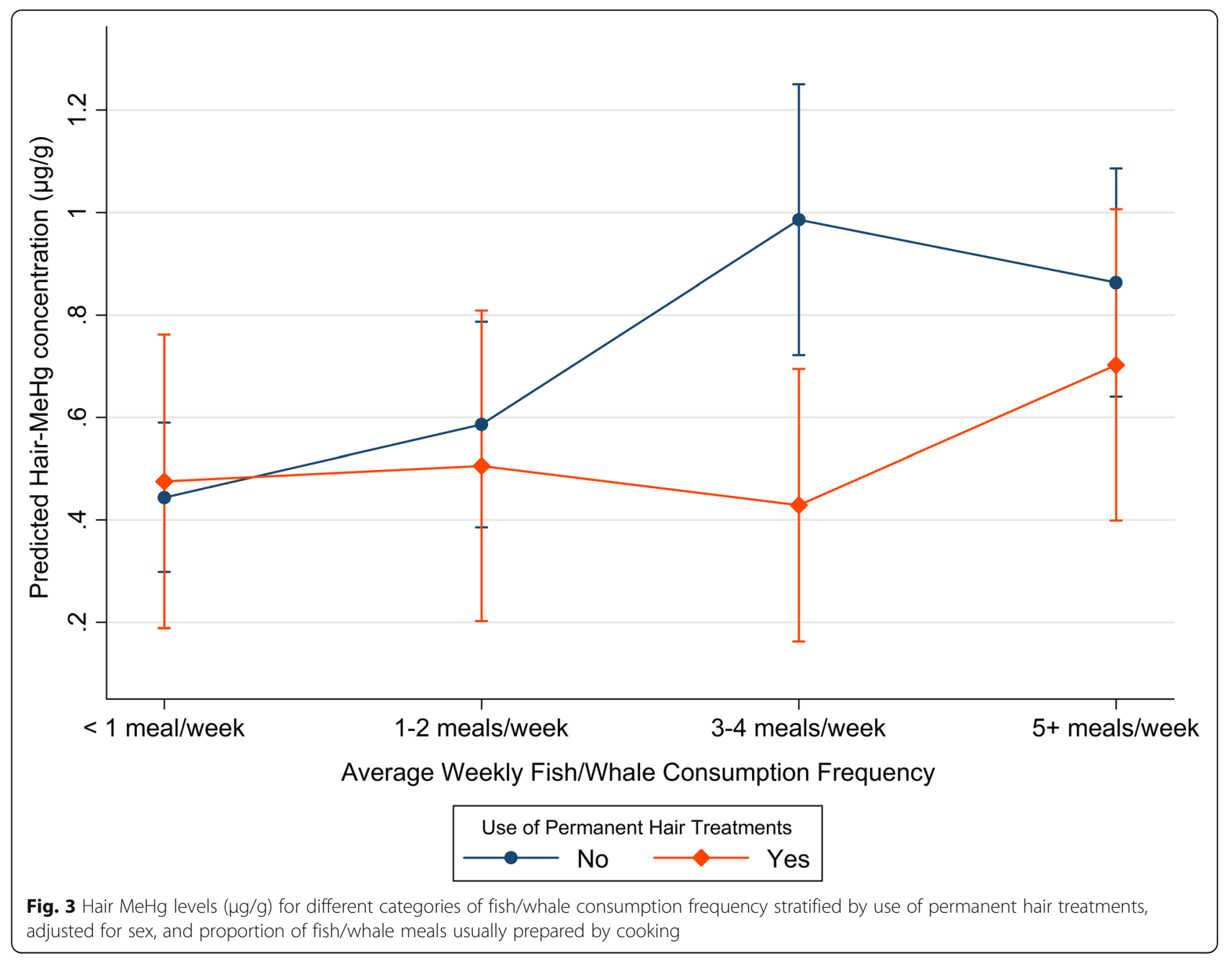

exposure level. However, given all participants had hair$\mathrm{MeHg}$ concentrations that were substantially below the Health Canada cut off for safe MeHg levels, it seems unlikely that any participant would have had excessive exposure at another time of year.
In addition to inaccuracies in classifying exposure time windows based on hair length, the accuracy of reporting food frequencies by season may be higher for seasons closer to the time of data collection. Given that hair length is not associated with fish consumption, however,

Table 4 Sensitivity Analysis: Multivariable regression of hair MeHg concentrations ( $\mu \mathrm{g} / \mathrm{g}$ ) on fish/whale intake, comparing models using measured MeHg values to models using values adjusted for variability in MeHg measurements observed in subsets of the study population, 101 western Canadian Arctic residents, 2016

\begin{tabular}{|c|c|c|c|c|c|c|}
\hline \multirow{2}{*}{$\begin{array}{l}\text { Fish/Whale } \\
\text { Intake (meals/week) }\end{array}$} & \multicolumn{2}{|c|}{ Original MeHg Measurement } & \multicolumn{2}{|c|}{ Adjusted MeHg Measurement $1^{\text {a }}$} & \multicolumn{2}{|c|}{ Adjusted MeHg Measurement $2^{b}$} \\
\hline & $\beta$ & $95 \% \mathrm{Cl}$ & $\beta$ & $95 \% \mathrm{Cl}$ & $\beta$ & $95 \% \mathrm{Cl}$ \\
\hline$<1$ & Ref & & Ref & & Ref & \\
\hline $1-2$ & 0.142 & $-0.106,0.391$ & 0.172 & $-0.129,0.473$ & 0.112 & $-0.084,0.309$ \\
\hline $3-4$ & 0.542 & $0.235,0.849$ & 0.656 & $0.284,1.028$ & 0.428 & $0.185,0.671$ \\
\hline$\geq 5$ & 0.419 & $0.152,0.689$ & 0.507 & $0.184,0.831$ & 0.331 & $0.120,0.543$ \\
\hline
\end{tabular}

${ }^{a} \mathrm{MeHg}$ concentrations adjusted by the mean percent change of 15.8\% estimated among 27 individuals with repeat measurements (excluding 1 outlier). MeHg concentration was increased by $15.8 \%$ for a random selection of $36 \%$ of participants and decreased by $15.8 \%$ for the remaining $64 \%$, based on the distribution of increased or decreased values in the validation subset

${ }^{\mathrm{b}} \mathrm{MeHg}$ concentrations adjusted according to reported use of permanent hair treatments: Among participants who used hair treatments, $50 \%$ were increased by the $38.5 \%$ mean percent change observed among 6 participants in the validation subset with reported use of permanent hair treatments; among those who did not use permanent hair treatments, $32 \%$ were increased by the $16.2 \%$ mean percent change observed among 22 participants in the validation subset who did not use permanent hair treatments 
it seems likely that misclassification resulting from inaccuracies would be independent and non-differential. The accuracy of consumption data and hair $\mathrm{MeHg}$ measurements is evident in the consistency of our results with the existing body of evidence on the relation of fish/ whale consumption to hair mercury concentration [ 9 , 63], as well as the inverse relationship we observed between hair length and $\mathrm{MeHg}$ concentrations. Another source of variation arises from measurements of distal ends of strands that have been growing for extended periods of time; although $\mathrm{MeHg}$ remains much more chemically stable in hair relative to other tissues, some of it may be released over time, particularly if the cuticle sustains damage [34, 61, 62]. However, we were unable to collect hair samples in a way that consistently allowed us to identify the root end of the strands, prohibiting us from restricting hair samples to a maximum length. Our analyses were further limited by insufficient data for: precise estimation of effects of individual fish/whale species that participants reported consuming; examining effect modification by dietary factors; or stratifying on permanent hair treatments or hair length.

A major strength of this research its engagement of residents of Indigenous communities in the circumpolar north, who are particularly vulnerable to methylmercury contamination, in strong partnerships with scientists formed to conduct collaborative research that addresses questions for which community members seek answers. Engaging stakeholders in the design and conduct of research is a scientific advancement of increasingly recognized value in translational research. Little health research to date engages people who bear the disease burden in the design and conduct of biomedical research. This study is a novel example of communitydriven biomedical research in Indigenous Arctic communities. Community planning committees supported participant recruitment and guided the development of the fish-focused FFQ and the timing of hair sample collection. Community guidance facilitated collection of hair samples following the season of greatest exposure and incorporating commonly used names for aquatic species, which likely improved participants' ability to provide accurate consumption data.

\section{Conclusions}

This mercury exposure project revealed that a large proportion of western Arctic Canadians regularly consume a wide range of fish species, as well as Beluga Whale. While hair$\mathrm{MeHg}$ concentration increased with fish/whale consumption, hair--MeHg concentrations were well below the level of concern established by the government of Canada in all members of the study population. This study provides reassurance to subsistence fishers in this region, as it suggests that fish/whale consumption does not appear associated with unsafe levels of methylmercury exposure.

\section{Supplementary information}

Supplementary information accompanies this paper at https://doi.org/10. 1186/s12889-020-09133-2.

Additional file 1: Supplementary File 1. Fish-Focused Food Frequency Questionnaire developed for this research.

Additional file 2: Supplementary File 2. Supplementary Table 1: Fish and marine mammal species consumed at least once in the past 12 months by community, 101 western Canadian Arctic residents, 2016.

\section{Abbreviations}

MeHg: Methylmercury; CANHelp: Canadian North Helicobacter pylori; NT: Northwest Territories; YT: Yukon Territory; GC-ICP-MS: Gas

Chromatography Inductively Coupled Plasma-Mass Spectrometry; FFQ: Food Frequency Questionnaire; Cl: Confidence Intervals; SD: Standard Deviation;

IQR: Interquartile Range

\section{Acknowledgements}

The authors would like to acknowledge Dr. Christian Abnet for his contributions to this work. The authors would also like to acknowledge the hard work of the members of the Canadian North Helicobacter pylori Working Group. Our team is fortunate to include several representatives from northern communities, who have been instrumental in the success of this research through their participation on community planning committees.

The authors would also like to thank the community nurses and community health center staff for their support.

\section{Authors' contributions}

This work was completed as part of EW's PhD dissertation. EW designed the study with input from $Y Y, S G$ and KG. EW collected and analyzed the data and wrote the manuscript. YY, SG and KG reviewed the draft and KG edited the manuscript. The authors have read and approved the manuscript.

\section{Funding}

This work was supported by grants from ArcticNet Network of Centres of Excellence of Canada; the Canadian Institutes for Health Research [MOP115031, IPH108285, 90386]; Alberta Innovates Health Solutions [201201159]; Northern Scientific Training Program; and Ualberta North. Inkind support for fieldwork came from Canadian North airlines and Olympus Canada. The funding bodies had no role in study design, data collection, data analysis, data interpretation, or in writing the manuscript.

\section{Availability of data and materials}

All data collected or created in partnership with Indigenous communities is considered confidential, sensitive and vulnerable to misappropriation. Data generated by this research cannot be shared without explicit permission from the communities who participated in the research. Researchers who are interested in obtaining data can send a proposal to the corresponding author for consideration by community planning committees. Data can only be made available if permission is granted by the community planning committees.

\section{Ethics approval and consent to participate}

This research received ethics approval from the University of Alberta Health Research Ethics Board (HREB), as a component of the project "Addressing Community Concerns about Risks from H. pylori Infection in the Circumpolar North"; Study ID: MS21_Pro00007868, Amendment ID: Pro00007868_AME17, approval date September 19, 2016. Study staff provided each participant an information sheet that outlined the study objectives, methods, information to be collected, benefits and potential risks of participation and confidentiality protection measures. Following review of this document, each consenting participant filled out a written consent form, confirming they had received enough information about the project and agreed to participate. Project information sheets and consent forms were approved by the Human Research Ethics Board, at the University of Alberta and have been published previously [19]. 


\section{Consent for publication}

Not Applicable.

\section{Competing interests}

The authors have no competing interests to declare.

\section{Author details}

${ }^{1}$ Faculty of Medicine and Dentistry, University of Alberta, Edmonton, Canada. ${ }^{2}$ School of Public Health, University of Alberta, Edmonton, Alberta, Canada. ${ }^{3}$ Department of Laboratory Medicine and Pathology, University of Alberta, Edmonton, Canada.

Received: 25 April 2020 Accepted: 16 June 2020

Published online: 06 July 2020

\section{References}

1. Agency for Toxic Substances and Disease Registry (ATSDR). ATSDR toxicological profile: mercury. Published online 1999. Accessed 18 Nov 2014. http://www.atsdr.cdc.gov/ToxProfiles/tp.asp?id=115\&tid=24

2. Patrick L. Mercury toxicity and antioxidants: part 1: role of glutathione and alphalipoic acid in the treatment of mercury toxicity. Altern Med Rev. 2002;7(6):456-71.

3. Crinnion WJ. Environmental medicine, part three: long-term effects of chronic low-dose mercury exposure. Altern Med Rev. 2000;5(3):209-23.

4. Carrier G, Bouchard M, Brunet RC, Caza M. A Toxicokinetic model for predicting the tissue distribution and elimination of organic and inorganic mercury following exposure to methyl mercury in animals and humans. II. Application and validation of the model in humans. Toxicol Appl Pharmacol. 2001;171(1):50-60. https://doi.org/10.1006/taap.2000.9113.

5. Selin NE. Global biogeochemical cycling of mercury: a review. Annu Rev Env Resour. 2009;34(1):43-63. https://doi.org/10.1146/annurev.environ.051308.084314.

6. Boyd AS, Seger D, Vannucci S, Langley M, Abraham JL, King LE. Mercury exposure and cutaneous disease. J Am Acad Dermatol. 2000;43(1 Pt 1):8190. https://doi.org/10.1067/mjd.2000.106360.

7. Agency for Toxic Substances and Disease Registry (ATSDR). ATSDR toxicological profile: mercury. Published online 2013. Accessed 18 Nov 2014. http://www.atsdr.cdc.gov/ToxProfiles/tp.asp?id=115\&tid=24

8. Castoldi AF, Coccini T, Ceccatelli S, Manzo L. Neurotoxicity and molecular effects of methylmercury. Brain Res Bull. 2001;55(2):197-203. https://doi.org/ 10.1016/S0361-9230(01)00458-0.

9. Chan HM, Receveur O. Mercury in the traditional diet of indigenous peoples in Canada. Environ Pollut. 2000;110(1):1-2. https://doi.org/10.1016/S02697491(00)00061-0.

10. NT Health and Social Services. General fish consumption guidelines for the NWT. Published online 2016. http://www.hss.gov.nt.ca/sites/www.hss.gov.nt. ca/files/general-fish-consumption-guidelines-nwt.pdf.

11. Yukon Contaminants Committee. Mercury in Yukon fish. Published online 2010. www.hss.gov.yk.ca/pdf/mercuryfish_en.pff.

12. Cheung J, Goodman K, Munday R, Heavner K, Huntington J, Morse J, et al. Helicobacter pylori infection in Canada's arctic: searching for the solutions. Can J Gastroenterol. 2008;22(11):912-6.

13. Hastings EV, Yasui Y, Hanington P, Goodman KJ. CANHelp working group. Community-driven research on environmental sources of $\mathrm{H}$. pylori infection in arctic Canada. Gut Microbes. 2014;5(5):606-17. https://doi.org/10.4161/ 19490976.2014.969639.

14. Gwich'in Social and Cultural Institute. Aklavik: the Gwich'in. Published 2006. http://www.gwichin.ca/TheGwichin/aklavik.html

15. Statistics Canada. Aklavik, Northwest Territories (Code6107025) (table). 2006 community profiles. 2006 census. Statistics Canada catalogue no. 92-591XWE; 2007. Accessed 8 Nov 2012. http://www12.statcan.gc.ca/censusrecensement/2006/dp-pd/prof/92-591/details/Page.cfm?Lang=E\&Geo1= CSD\&Code $1=6107025 \&$ Geo2 $=$ PR\&Code2 $=61 \&$ Data $=$ Count $\&$ SearchText $=$ Aklavik\&SearchType=Begins\&SearchPR=61\&B1=All\&Custom $=$.

16. Council of Yukon First Nations. Gwich'in Tribal Council. www.cyfn.ca/ ourhistory. Accessed Nov 82012.

17. Statistics Canada. Old crow, Yukon (code 6001043) and Yukon, Yukon (code 6001) (table). Census profile. 2011 census. Statistics Canada catalogue no. 98-316-XWE; 2012.

18. Statistics Canada. Fort McPherson, Northwest Territories (code 6101015) and Northwest Territories (code 61) (table). Census profile. 2011 census. Statistics Canada catalogue no. 98-316-XWE; 2012.
19. Walker EV. Community-driven research in the Canadian Arctic: investigating the effect of dietary exposure to methylmercury on the severity of chronic inflammation and gastric neoplasia in populations with an elevated risk of gastric cancer. Published online 2017

20. Committee on the Toxicological Effects of Methylmercury, Board on Environmental Studies and Toxicology, National Research Council. Chemistry, Exposure, Toxicokinetics, and Toxicodynamics. Toxicological effects of methylmercury; 2000. Accessed 4 Nov 2015. http://www.ncbi.nIm. nih.gov/books/NBK225779/.

21. Esteban M, Castaño A. Non-invasive matrices in human biomonitoring: a review. Environ Int. 2009:35(2):438-49. https://doi.org/10.1016/j.envint.2008.09.003.

22. Elhamri H, Idrissi L, Coquery M, Azemard S, El Abidi A, Benlemlih M, et al. Hair mercury levels in relation to fish consumption in a community of the Moroccan Mediterranean coast. Food Addit Contam. 2007;24(11):1236-46. https://doi.org/10.1080/02652030701329611.

23. Berglund M, Lind B, Björnberg KA, Palm B, Einarsson O, Vahter M. Interindividual variations of human mercury exposure biomarkers: a crosssectional assessment. Environ Health. 2005;4:20. https://doi.org/10.1186/ 1476-069X-4-20

24. Ohno T, Sakamoto M, Kurosawa T, Dakeishi M, Iwata T, Murata K. Total mercury levels in hair, toenail, and urine among women free from occupational exposure and their relations to renal tubular function. Environ Res. 2007;103(2):191-7. https://doi.org/10.1016/j.envres.2006.06.009.

25. Dorea J, Barbosa AC, Ferrari I, de Souza JR. Mercury in hair and in fish consumed by riparian women of the Rio Negro, Amazon, Brazil. Int J Environ Health Res. 2003;13(3):239-48. https://doi.org/10.1080/ 0960312031000122398.

26. Castilhos ZC, Rodrigues-Filho S, Rodrigues APC, Villas-Bôas RC, Siegel S, Veiga MM, et al. Mercury contamination in fish from gold mining areas in Indonesia and human health risk assessment. Sci Total Environ. 2006;368(1): 320-5. https://doi.org/10.1016/j.scitotenv.2006.01.039.

27. Carrington CD, Bolger MP. An exposure assessment for methylmercury from seafood for consumers in the United States. Risk Anal. 2002;22(4):689-99.

28. Bjornberg KA, Vahtera M, Grawe KP, Berglund M. Methyl mercury exposure in Swedish women with high fish consumption. Sci Total Environ. 2005; 341(1-3):45-52. https://doi.org/10.1016/j.scitotenv.2004.09.033.

29. Barbosa AC, Jardim W, Dorea JG, Fosberg B, Souza J. Hair mercury speciation as a function of gender, age, and body mass index in inhabitants of the Negro River basin, Amazon, Brazil. Arch Environ Contam Toxicol. 2001;40(3):439-44.

30. Agusa T, Kunito T, Iwata H, Monirith I, Tana TS, Subramanian A, et al. Mercury contamination in human hair and fish from Cambodia: levels, specific accumulation and risk assessment. Environ Pollut. 2005;134(1):79-86. https://doi.org/10.1016/j.envpol.2004.07.015.

31. Ikingura JR, Akagi $H$. Monitoring of fish and human exposure to mercury due to gold mining in the Lake Victoria goldfields, Tanzania. Sci Total Environ. 1996;191(1-2):59-68. https://doi.org/10.1016/0048-9697(96)05178-9.

32. Zhang $\mathrm{L}$, Wong $\mathrm{MH}$. Environmental mercury contamination in China: sources and impacts. Environ Int. 2007;33(1):108-21. https://doi.org/10.1016/ j.envint.2006.06.022.

33. Boumba VA, Ziavrou KS, Vougiouklakis T. Hair as a biological indicator of drug use, drug abuse or chronic exposure to environmental toxicants. Int J Toxicol (Taylor \& Francis). 2006;25(3):143-63. https://doi.org/10.1080/ 10915810600683028.

34. White L, Paschal D, Baratz R, Seidel S, Clarckson T, Harkins D, et al. Hair analysis panel discussion: exploring the state of the science: ATSDR (Agency for Toxic Substances and Disease Registry); 2001. http://www.atsdr.cdc.gov/ HAC/hair_analysis/3.0.html.

35. Maclntosh DL, Spengler JD. Human exposure assessment. Geneva: World Health Organization; 2000. https://doi.org/10.1186/s12889-020-09133-2.

36. Appenzeller BMR, Tsatsakis AM. Hair analysis for biomonitoring of environmental and occupational exposure to organic pollutants: state of the art, critical review and future needs. Toxicol Lett. 2012;210(2):119-40. https://doi.org/10.1016/j.toxlet.2011.10.021.

37. Centers for Disease Control (CDC). National Health and nutrition examination survey: specimen collection procedures manual. Published online 2000.

38. Laffont L, Maurice L, Amouroux D, Navarro P, Monperrus M, Sonke JE, et al. Mercury speciation analysis in human hair by species-specific isotopedilution using GC-ICP-MS. Anal Bioanal Chem. 2013:405:3001-10.

39. Tekran Instruments. Series 2700 application note: AN2700_02(a) - hair and biota series 2700 Methylmercury analysis in human hair and biota using 4M HNO3. Published online 20111994. 
40. Willett W. Nutritional epidemiology: Oxford University Press; 2012.

41. Bradley MA, Barst BD, Basu N. A review of mercury bioavailability in humans and fish. Int J Environ Res Public Health. 2017;14(2):169.

42. Chapman L, Chan HM. The influence of nutrition on methyl mercury intoxication. Environ Health Perspect. 2000;108(Suppl 1):29-56.

43. Health Canada, Environment Canada. Risk management strategy for mercury. Health Canada; 2010. https://www.ec.gc.ca/doc/mercuremercury/1241/index_e.htm.

44. Rothman KJ, Greenland S, Lash TL. Modern epidemiology: Lippincott Williams \& Wilkins; 2008

45. Hosmer DW, Lemeshow S. Applied logistic regression: Wiley; 2000

46. Al-Majed NB, Preston MR. Factors influencing the total mercury and methyl mercury in the hair of the fishermen of Kuwait. Environ Pollut. 2000;109(2): 239-50. https://doi.org/10.1016/S0269-7491(99)00261-4.

47. Bonsignore M, Tamburrino S, Oliveri E, Marchetti A, Durante C, Berni A, et al. Tracing mercury pathways in Augusta bay (southern Italy) by total concentration and isotope determination. Environ Pollut. 2015;205:178-85. https://doi.org/10.1016/j.envpol.2015.05.033.

48. Schaefer AM, Jensen EL, Bossart GD, Reif JS. Hair mercury concentrations and fish consumption patterns in Florida residents. Int J Environ Res Public Health. 2014;11(7):6709-26. https://doi.org/10.3390/ ijerph110706709.

49. Traynor S, Kearney G, Olson D, Hilliard A, Palcic J, Pawlowicz M. Fish consumption patterns and mercury exposure levels among women of childbearing age in Duval County, Florida. J Environ Health. 2013;75(6): 8-15.

50. Black FJ, Bokhutlo T, Somoxa A, Maethamako M, Modisaemang O, Kemosedile T, et al. The tropical African mercury anomaly: lower than expected mercury concentrations in fish and human hair. Sci Total Environ. 2011;409(10):1967-75. https://doi.org/10.1016/j.scitotenv.2010.11. 027.

51. Lincoln RA, Shine JP, Chesney EJ, Vorhees DJ, Grandjean P, Senn DB. Fish consumption and mercury exposure among Louisiana recreational anglers. Environ Health Perspect. 2011;119(2):245-51. https://doi.org/10.1289/ehp.1002609.

52. Karouna-Renier NK, Rao KR, Lanza JJ, Rivers SD, Wilson PA, Hodges DK, et al. Mercury levels and fish consumption practices in women of child-bearing age in the Florida panhandle. Environ Res. 2008;108(3):320-6. https://doi. org/10.1016/j.envres.2008.08.005.

53. Xue F, Holzman C, Rahbar MH, Trosko K, Fischer L. Maternal fish consumption, mercury levels, and risk of preterm delivery. Environ Health Perspect. 2007;115(1):42-7. https://doi.org/10.1289/ehp.9329.

54. Knobeloch L, Gliori G, Anderson $\mathrm{H}$. Assessment of methylmercury exposure in Wisconsin. Environ Res. 2007;103(2):205-10. https://doi.org/10.1016/j. envres.2006.05.012.

55. Salehi Z, Esmaili-Sari A. Hair mercury levels in pregnant women in Mahshahr, Iran: fish consumption as a determinant of exposure. Sci Total Environ. 2010; 408(20):4848-54. https://doi.org/10.1016/j.scitotenv.2010.06.027.

56. Olivero-Verbel J, Caballero-Gallardo K, Negrete-Marrugo J. Relationship between localization of gold mining areas and hair mercury levels in people from bolivar, north of Colombia. Biol Trace Elem Res. 2011;144(1-3): 118-32. https://doi.org/10.1007/s12011-011-9046-5.

57. Okati N, Sari AE, Ghasempouri SM. Hair mercury concentrations of lactating mothers and breastfed infants in Iran (fish consumption and mercury exposure). Biol Trace Elem Res. 2012;149(2):155-62. https://doi.org/10.1007/ s12011-012-9424-7.

58. Michalak I, Chojnacka K, Saeid A, Mikulewicz M. Research on mercury levels in scalp hair. Pol J Environ Stud. 2014;23(3):793-800.

59. Dong Z, Jim RC, Hatley EL, Backus ASN, Shine JP, Spengler JD, et al. A longitudinal study of mercury exposure associated with consumption of freshwater fish from a reservoir in rural south Central USA. Environ Res. 2015;136:155-62. https://doi.org/10.1016/j.envres.2014.09.029.

60. Agah H, Leermakers M, Gao Y, Fatemi SMR, Katal MM, Baeyens W, et al. Mercury accumulation in fish species from the Persian Gulf and in human hair from fishermen. Environ Monit Assess. 2010;169(1-4):203-16. https://doi. org/10.1007/s10661-009-1162-8

61. Pragst F, Balikova M. State of the art in hair analysis for detection of drug and alcohol abuse. Clin Chim Acta. 2006;370(1-2):17-49.

62. Harkins DK, Susten AS. Hair analysis: exploring the state of the science. Environ Health Perspect. 2003;111(4):576-8.
63. Beldowska M, Falkowska L. Mercury in marine fish, mammals, seabirds, and human hair in the coastal zone of the southern Baltic. Water Air Soil Pollut. 2016;227(2):52. https://doi.org/10.1007/s11270-015-2735-5.

\section{Publisher's Note}

Springer Nature remains neutral with regard to jurisdictional claims in published maps and institutional affiliations.
Ready to submit your research? Choose BMC and benefit from:

- fast, convenient online submission

- thorough peer review by experienced researchers in your field

- rapid publication on acceptance

- support for research data, including large and complex data types

- gold Open Access which fosters wider collaboration and increased citations

- maximum visibility for your research: over $100 \mathrm{M}$ website views per year

At BMC, research is always in progress.

Learn more biomedcentral.com/submissions 